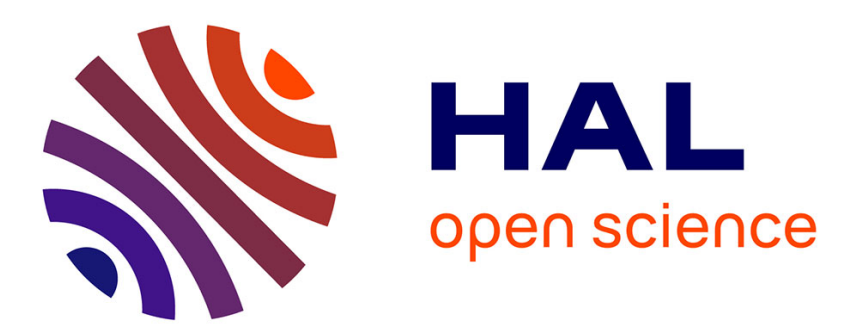

\title{
Use of Polar Organic Chemical Integrative Samplers to assess the effects of chronic pesticide exposure on biofilms
}

Soizic Morin, S. Pesce, S. Kim Tiam, X. Libert, Marina Coquery, Nicolas

Mazzella

\section{To cite this version:}

Soizic Morin, S. Pesce, S. Kim Tiam, X. Libert, Marina Coquery, et al.. Use of Polar Organic Chemical Integrative Samplers to assess the effects of chronic pesticide exposure on biofilms. Ecotoxicology, 2012, 21 (5), pp.1570-1580. 10.1007/s10646-012-0910-7 . hal-00712609

\section{HAL Id: hal-00712609 \\ https://hal.science/hal-00712609}

Submitted on 27 Jun 2012

HAL is a multi-disciplinary open access archive for the deposit and dissemination of scientific research documents, whether they are published or not. The documents may come from teaching and research institutions in France or abroad, or from public or private research centers.
L'archive ouverte pluridisciplinaire HAL, est destinée au dépôt et à la diffusion de documents scientifiques de niveau recherche, publiés ou non, émanant des établissements d'enseignement et de recherche français ou étrangers, des laboratoires publics ou privés. 
Author-produced version of the article published in Ecotoxicology,2012, vol. 21 (5), 1570-1580.

The original publication is available at http://www.springerlink.com

doi : 10.1007/s10646-012-0910-7

\title{
Use of Polar Organic Chemical Integrative Samplers to assess the effects of chronic pesticide exposure on biofilms
}

Soizic Morin ${ }^{1}$, Stéphane Pesce ${ }^{2}$, Sandra Kim-Tiam¹, Xavier Libert ${ }^{1}$, Marina Coquery², Nicolas Mazzella1

${ }^{1}$ Irstea, UR REBX, 50 avenue de Verdun, 33612 Cestas cedex, France

2 Irstea, UR MALY, 3 bis quai Chauveau - CP220, 69336 Lyon, France

\begin{abstract}
The responses of aquatic organisms to chronic exposure to environmental concentrations of toxicants, often found in mixtures, are poorly documented. Here passive sampler extracts were used in experimental contamination of laboratory channels, to investigate their effects on natural biofilm communities. A realistic mixture of pesticides extracted from POCIS (Polar Organic Chemical Integrative Samplers) was used to expose biofilms in laboratory channels to total pesticide concentrations averaging $0.5 \pm 0.1 \mu \mathrm{g} \cdot \mathrm{l}^{-1}$. The level of exposure was representative of field conditions in terms of relative proportions of the substances but the exposure concentration was not maintained (decreasing concentrations between contamination occasions). The impact on the structural as well as the functional characteristics of the autotrophic and heterotrophic components was determined, using biofilm grown in uncontaminated conditions (reference site) and in sites exposed to pesticides (contaminated site). The exposure imposed did not significantly modify the structure or functions of reference
\end{abstract}


Author-produced version of the article published in Ecotoxicology,2012, vol. 21 (5), 1570-1580.

The original publication is available at http://www.springerlink.com

doi : $10.1007 / \mathrm{s} 10646-012-0910-7$

biofilms, nor did it modify tolerance as measured by mixture $\mathrm{EC}_{50}\left(\mathrm{EC}_{50} \mathrm{mix}\right)$. In contrast, the communities from the more contaminated downstream section lost tolerance following decreased dose exposure, but community composition remained fairly stable. Overall, these results indicate that low levels of contamination did not lead to strong changes in community structure, and 14-day changes in tolerance seemed to depend mainly on physiological adaptation, suggesting that other environmental factors or longer-lasting processes prevailed. This study reports the first attempt to use passive sampler extracts as a realistic composite contaminant for experimental exposure of biofilms, with promising perspectives in further ecotoxicology studies.

\section{Keywords}

Periphyton; realistic pesticide mixtures; POCIS extracts; low dose; tolerance; diatoms

\section{Introduction}

Pesticide contamination of the environment and the subsequent responses of periphytic communities to pollutants are often studied using the PICT (pollution-induced community tolerance) method. This approach is based upon the assumption that a community that has been previously exposed to a substance or group of substances would acquire tolerance (physiological and/or structural) to these pollutants greater than that of comparable communities which had not suffered such conditions (Blanck et al. 1988). Thus, differences in tolerance, which can be evaluated by short-term bioassays with increasing toxic concentration(s), can reveal a posteriori the exposure history of a biological community. This kind of approach is particularly suitable for dealing with 
Author-produced version of the article published in Ecotoxicology,2012, vol. 21 (5), 1570-1580.

The original publication is available at http://www.springerlink.com

doi : $10.1007 / \mathrm{s} 10646-012-0910-7$

complex entities such as periphytic communities (Tlili and Montuelle 2011). The tolerance acquired by periphytic communities, measured in this way, leads on the one hand to a physiological adaptation of individuals, but also to a structural modification of communities (Dorigo et al. 2007; Duong et al. 2008; Morin et al. 2010a).

Recently, the assessment of communities' responses to more environmentally realistic contaminations (i.e. mixtures of toxicants directly taken from the surface water of a small river) has been developed by coupling ecotoxicological tests with passive samplers (Escher et al. 2006; Shaw et al. 2009). Using naturally occurring biofilm communities and pesticide extracts from POCIS (Polar Organic Chemical Integrative Samplers, Alvarez et al. 2004), Pesce et al. (2011) performed short-term photosynthesis bioassays. Their study revealed that such an approach could offer promising perspectives to evaluate the effects of pesticide on aquatic ecosystems, especially with a view to implementing PICT assessment for mixtures.

Understanding the hazards of low-dose contaminant cocktails is a growing concern for ecotoxicologists (Artigas et al. 2012). It is also essential for decision making, with the implementation of environmental policies regulating and/or reducing pesticide use and inputs in the aquatic environment (e.g. French and European incentives such as Plan Ecophyto 2018, European directive for a sustainable use of pesticides). In this context, methods are needed to improve exposure assessment linking it with adverse effects on the biota. Developing laboratory studies of the impacts of realistic pesticides mixtures on the biota is challenging due to the variety of other confounding factors in situ that may mitigate the biological responses observed in contaminated environments. Recent developments in environmental chemistry, such as passive sampling, provide 
Author-produced version of the article published in Ecotoxicology,2012, vol. 21 (5), 1570-1580.

The original publication is available at http://www.springerlink.com

doi : 10.1007/s10646-012-0910-7

reliable quantification of chemicals in the environment (e.g. Mazzella et al. 2010). Among passive samplers, POCIS pre-concentrate polar pesticides from water bodies.

The main aims of this work were thus: i) to test the use of extracts from POCIS (previously exposed in situ) for contaminating laboratory channels with complex mixtures of pesticides, and ii) to examine the responses of biofilm communities following chronic exposure to low doses of such a mixture of agricultural pesticides.

Accordingly, biofilm communities were collected from an upstream (considered as reference) and a downstream (contaminated) site of a small river located in a French vineyard area. They were then exposed for two weeks to low doses of a pesticide mixture (directly extracted from POCIS) in indoor artificial channels. Chronic effects of the pesticide mixture were estimated on biofilm structure (biomass and algal community structure), diatom diversity and biofilm function (photosynthesis and substrate-induced respiration). Levels of tolerance of phototrophic communities to the pesticide mixture were also estimated using an original PICT approach, based on shortterm photosynthetic bioassays with the POCIS extracts. Exposure to POCIS extracts was expected to provoke structural and/or functional changes in the communities from both reference and contaminated (decrease in exposure) sites.

\section{Materials and methods}

Experimental design

Pre-exposure period 
Author-produced version of the article published in Ecotoxicology,2012, vol. 21 (5), 1570-1580.

The original publication is available at http://www.springerlink.com

doi : 10.1007/s10646-012-0910-7

River water and natural biofilms (growing on stones) were sampled in June 2010, on two sites located along the Morcille River, in the Beaujolais vineyard area, eastern France $\left(46.150^{\circ} \mathrm{N}, 4.600^{\circ} \mathrm{E}\right)$. This small shallow river (Strahler order 1 ) has been extensively studied over the last decades (Montuelle et al. 2010). The sites selected present $6.7 \%$ vineyard cover upstream (reference site) and 79\% downstream (contaminated site), leading to a gradient in nutrients and pesticides in the water. The watershed is underlain by granite, and the river bed mainly composed of pebbles and sand. At both sites, river water and biofilm inocula obtained by scraping stones were collected and brought back to the laboratory for a 2-week colonization period in aquaria (see Laboratory experiment). Simultaneously, POCIS devices were immersed at the downstream site to catch the polar organic contaminants present in surface waters during the same 2 weeks (biofilm colonization period).

\section{Laboratory experiment}

In the laboratory, biofilm inocula collected from each sampling site (reference and contaminated sites) were introduced to separate aquaria containing 50 litres of corresponding river water (Table 1), and left for two weeks to allow biofilm colonization on artificial substrates (glass microscope slides) previously placed at the bottom of each aquarium.

At the beginning of the experiment (day 0), glass slides were placed in artificial channels (Figure 1) and exposed for two weeks in different conditions, noted R (reference biofilms and conditions), C (contaminated biofilms and conditions) and R/C (reference biofilms under contaminated conditions). More specifically, R samples (taken as control samples) corresponded to colonized slides from upstream (reference site) fed with artificial clean water; they were collected in triplicate channels connected to the same 
Author-produced version of the article published in Ecotoxicology,2012, vol. 21 (5), 1570-1580.

The original publication is available at http://www.springerlink.com

doi : $10.1007 / \mathrm{s} 10646-012-0910-7$

tank (Figure 1A), and in another independent series (Figure 1B). R/C samples corresponded to colonized slides from reference site that were exposed in the channels to POCIS extracts, to obtain low dose contamination by pesticide mixtures; they were sampled from triplicate channels all connected to a 9l-tank (Figure 1A), and from another independent series fed by a 3l-tank (Figure 1B), to assess between-channel variability. Finally, C samples corresponded to one set of colonized slides from downstream (contaminated site) that was kept in artificial stream water in which POCIS extracts were added (Figure 1B).

All channels were fed with artificial water (prepared as described by Ylla et al. (2009) and supplemented with nutrients to reach concentrations from reference site). In treatments with pesticide addition (treatments R/C and C), POCIS extracts were added directly in the tanks. The channels were under continuous water flow operated by individual pumps (one per channel, Rena RFPN P600, 580l- $\mathrm{min}^{-1}$ ) and a 10:14 light/dark cycle was imposed (incident light intensity: $150 \mu \mathrm{mol} \cdot \mathrm{m}^{-2} \cdot \mathrm{s}^{-1}$ ). The physicochemical conditions were monitored throughout the 14 days of the experiment, and the water was totally renewed in the middle of the experiment to ensure a certain level of contamination.

Pesticide exposure

In situ time-weighted average (TWA) concentrations of polar organic pesticides in the river during biofilm colonization were determined by immersion of triplicate "quantitative" POCIS (Mazzella et al. 2010) in the Morcille River at both reference and contaminated sites for two consecutive 14-day periods prior to the laboratory experiment. These "quantitative" POCIS were spiked with a performance reference compound (PRC: deuterium labeled atrazine-desisopropyl) to compensate for variations 
Author-produced version of the article published in Ecotoxicology,2012, vol. 21 (5), 1570-1580.

The original publication is available at http://www.springerlink.com

doi : 10.1007/s10646-012-0910-7

in exchange kinetics under field conditions (Mazzella et al. 2010). Sixteen “accumulative" POCIS (without PRC) were exposed for 14 days at the downstream station (contaminated site) to obtain pre-concentrated extracts by elution of the receiving phase. Both "quantitative" and "accumulative" POCIS were exposed in independent but identical deployment devices, perpendicular to the water surface and facing to the flow. The 16 POCIS extracts were reconstituted in $80 \mathrm{ml}$ of mineral water (Evian). Analyte concentrations in this stock solution are given in Table 1. Of the 80-ml suspension, $10 \mathrm{ml}$ (i.e. the mixture corresponding to 2 POCIS) were used for contamination of $\mathrm{R} / \mathrm{C}$ and $\mathrm{C}$ experimental systems on day 0 . The water was changed in each channel after 7 days (mid-experiment), and then spiked with $10 \mathrm{ml}$ (2 POCIS) to reset pesticides concentrations (Table 1). $40 \mathrm{ml}$ (8 POCIS) of the same stock solution were used for subsequent toxicity tests (PICT measurements). During the experimental period, 50-ml water samples were collected four times: at the beginning of the experiment (day 0), before and after the mid-experiment water change (day 7) and at the end of the exposure period (day 14). The method developed by Lissalde et al. (2011)was used for the analysis of water samples collected in the channels, after a solid phase extraction step, but also for the analysis of POCIS extracts. Pre-concentration of the water samples was performed using SPE cartridges Chromabond HR-X (MachereyNagel). The solid receiving phase contained by the POCIS (Oasis HLB sorbent) was recovered in ultrapure water. Then all samples were analyzed by HPLC-ESI-MS/MS (HPLC Ultimate 3000, Dionex, equipped with a Gemini NX C18 column, 10x2 mm, $3 \mu \mathrm{m}$, Phenomenex, and API 2000 triple quadrupole, AB SCIEX equipped with an electrospray ionization source). In addition, water samples from each channel were analyzed using GC-MS/MS (Quantum GC, Thermo, equipped with a Rxi-5MS column $30 \mathrm{~m}$ x $0.25 \mathrm{~mm}$ x $0.25 \mu \mathrm{m}$, Restek) on day 0 and day 14 for complementary determination of fungicides. 
Author-produced version of the article published in Ecotoxicology,2012, vol. 21 (5), 1570-1580.

The original publication is available at http://www.springerlink.com

doi : 10.1007/s10646-012-0910-7

From these measurements (a total of 6 analyses per treatment during the course of the experiment), average exposure throughout the experiment was determined (Table 2).

\section{In situ metal concentrations}

Copper (Cu) and arsenic (As) were identified as the most relevant elements for characterizing the metallic gradient of the Morcille watershed (Montuelle et al. 2010). In situ dissolved $\mathrm{Cu}$ and As were determined from two spot surface water samples collected in the Morcille River at reference and contaminated sites during the 14 days before the beginning of the experiment. Dissolved metal concentrations were determined after filtration of water samples using polyvinylidene fluoride membrane filters (porosity $0.45 \mu \mathrm{m}$, Millipore), acidification (Suprapur nitric acid, Merck, 0.5\% v/v) and storage at about $4^{\circ} \mathrm{C}$ before Inductively Coupled Plasma Mass Spectrometry analysis (ICP-MS X Series II, Thermo Electron). Quality controls were routinely made using a certified reference material (Environment Canada, TM 27-3, Lake Ontario natural water) (Choubert et al. 2009).

\section{Biofilm structure and functional endpoints}

Biofilms were collected just before contamination of $\mathrm{C}$ and $\mathrm{R} / \mathrm{C}$ channels and after two weeks of experiment in all modalities (with a minimum of three replicate slides per treatment and sampling date). Additional samples were collected along the experiment (2, 5 and 9 days after exposure) in the triplicate series of $\mathrm{R}$ and $\mathrm{R} / \mathrm{C}$ to follow the colonization process.

At each sampling date, glass slides were removed from the channels, scraped with a cutter blade and the surface film suspended in a standard volume of mineral water (10 $\mathrm{ml}$ per $\mathrm{cm}^{2}$ of scraped surface). Aliquots were devoted to determination of global 
Author-produced version of the article published in Ecotoxicology,2012, vol. 21 (5), 1570-1580.

The original publication is available at http://www.springerlink.com

doi : 10.1007/s10646-012-0910-7

biomass (dry mass and ash-free dry mass), phototrophic community-related parameters (chlorophyll measurements, photosynthetic activity, diatom cell numerations and community structure) and heterotrophic functions (respiration, enzymatic activities).

Biofilm dry weight (DW) and ash-free dry matter (AFDM) were measured as described in Morin et al. (2010a). Total chlorophyll a (Chl a) and the proportion of chlorophyceae, diatoms and cyanobacteria were determined by a multi-wavelength pulse-amplitude modulated (PAM)-fluorometer on a Phyto-PAM system (H. Walz, Effeltrich, Germany) following Schmitt-Jansen and Altenburger (2008). The effective quantum yield of photosystem II ( $\Phi_{\mathrm{PSII}}$, Baker 2008) was also estimated with the Phyto-PAM fluorometer (Schmitt-Jansen and Altenburger 2008). Aliquots preserved in formalin solution were used for live and dead diatom cell density enumeration (Morin et al. 2010b) and taxonomic identifications. The quantitative description of the diatom community was based on counting 10 random fields using a Nageotte counting chamber under light microscopy at 400x magnification (Olympus BX51 upright microscope, UK), distinguishing live and dead cells by the presence/absence of chloroplasts. For taxonomic analyses, samples were cleaned of their organic content and permanently mounted on microscope slides following European standard NF EN 13946 before identification of about 400 frustules per slide at 1000× magnification (Leica DMRB photomicroscope, Wetzlar, Germany). Identifications were performed to the lowest taxonomic level possible using standard references (Krammer and Lange-Bertalot 1986 - 1991) and recent nomenclature updates. Abnormalities in diatom morphology and/or ornamentations were also reported.

The heterotrophic community was targeted by measuring substrate-induced respiration (SIR) as described in Tlili et al. (2011). Briefly, SIR was measured using MicroResp ${ }^{\mathrm{TM}}$ 
Author-produced version of the article published in Ecotoxicology,2012, vol. 21 (5), 1570-1580.

The original publication is available at http://www.springerlink.com

doi : 10.1007/s10646-012-0910-7

microplates filled with biofilm suspension and a carbon substrate (D-glucose, Prolabo) and incubated for 15 hours at ambient temperature. Then, the quantity of $\mathrm{CO}_{2}$ released was measured by gas chromatography on an MTI 200 microcatharometer and the results were converted into $\mathrm{ngCO}_{2} \cdot \mathrm{g} \cdot \mathrm{cm}^{-2}$.

Finally, PICT measurements were performed to characterize the sensitivity of the biofilm to the mixtures of pesticides accumulated by the POCIS. Short-term photosynthetic bioassays using measurements of the optimal quantum yield (Baker 2008), $F_{v} / F_{m}$, of the biofilms exposed to semi-logarithmic series of dilutions of the preconcentrated extracts. Total pesticide concentrations used for PICT analyses ranged from about 0.2 to $600 \mu \mathrm{g} \cdot \mathrm{l}^{-1}$. Three replicate samples were taken, and run with 4 blanks in analytical triplicates with each of the seven concentrations of POCIS extracts. Biofilms were exposed for 48 hours in a climatic chamber (Versatile Environmental Test Chamber, Sanyo, MLR-350) at a constant temperature of $23^{\circ} \mathrm{C}$ under artificial light (1400 lux). Before Phyto-PAM measurements, they were kept in the dark for 30 minutes and $\mathrm{F}_{\mathrm{v}} / \mathrm{F}_{\mathrm{m}}$ was determined.

Data analysis

\section{Pesticides}

For concentrations below the quantification limits, a value equal to half of the method quantification limit was used for calculations (Helsel 1990). Correlations between the composition of extracts of "quantitative" and "accumulative" POCIS were calculated using XLSTAT v. 201.5.08 (Addinsoft 1995-2010) for rank correlations (Spearman coefficient) and linear dependence (Pearson coefficient). 
Author-produced version of the article published in Ecotoxicology,2012, vol. 21 (5), 1570-1580.

The original publication is available at http://www.springerlink.com

doi : 10.1007/s10646-012-0910-7

\section{Biofilm characteristics}

All biofilm characteristics were analyzed using the linear mixed effect model (LmE) for repeated measurements, to discriminate for each endpoint between time- and treatment-dependent effects. For this purpose, the treatments and sampling dates were set as fixed effects and samples as random effects to account for possible variability between "true" replicates (from independent channels) and pseudoreplicates (from channels connected to the same tank). LmEs were computed with the package nlme (Pinheiro et al. 2009) in the statistical modelling environment R (Ihaka and Gentleman 1996).

Between-sample similarities in diatom community structure were analyzed based on the species representing more than $2 \%$ relative abundance in at least one sample. Hierarchical cluster analyses were conducted with PC-Ord software (McCune and Mefford 1999), using the Bray-Curtis distance with complete linkage (furthest neighbour).

Optimal $\mathrm{EC}_{50}$ (half maximal effective concentration) values were calculated by performing a nonlinear regression on Hill's model for each triplicate, using the Regtox software (version EV7.0.5, E. Vindimian, http://eric.vindimian.9online.fr/).

\section{Relationships between environmental characteristics and biological responses}

Variance partitioning based on redundancy analysis was performed to determine the combined and single effects of the physical and chemical (including toxicants) parameters of the water on the biofilm characteristics. As biofilms are integrative over time, environmental parameters associated with biological samples corresponded to average conditions during the 14 days before sample collection. Data were standardized 
Author-produced version of the article published in Ecotoxicology,2012, vol. 21 (5), 1570-1580.

The original publication is available at http://www.springerlink.com

doi : $10.1007 / \mathrm{s} 10646-012-0910-7$

prior to analysis. Then redundancy analyses were performed to test the significance of the variables of interest. The analyses were conducted with the $\mathrm{R}$ package vegan (Oksanen et al. 2010).

\section{Results}

Pesticide exposure

Table 2 reports the main pesticides quantified in the field and in the channels, as well as the concentrations measured. The substances analysed (46 in the laboratory experiment, 33 in the field survey) were based on existing knowledge of this watershed (Rabiet et al. 2010). Among them, 12 were quantified.

In situ TWA concentrations during the period 8-22 June were very low upstream (reference site, total pesticide concentration $=0.09 \mu \mathrm{g} \cdot \mathrm{l}^{-1}$ ) in comparison to the downstream site (contaminated site, $1.71 \mu \mathrm{g} \cdot \mathrm{l}^{-1}$ ). The concentrations imposed in the channels, derived from the "accumulative" POCIS extracts, were anticipated with the knowledge of the sampling rates for the "accumulative" POCIS (Lissalde et al. 2011; Mazzella et al. 2007), i.e. about 3-4.5 litres of water were extracted by each POCIS exposed for 28 days. Consequently, at least 2 POCIS-equivalent extracts were used for spiking the channel volume (9 l) at day 0 , and after 7 days. Actual concentrations measured in the channels were $29 \%$ of downstream field concentrations in R/C, and of $46 \%$ in C. These differences were attributed to a loss by adsorption and/or photo- or biodegradation. Despite some differences regarding the quantitative aspects, both conditions corresponded to low dose exposure, and the most abundant substances observed at the downstream station (dimetomorph, diuron and N-(3,4-dichlorophenyl)- 
Author-produced version of the article published in Ecotoxicology,2012, vol. 21 (5), 1570-1580.

The original publication is available at http://www.springerlink.com

doi : 10.1007/s10646-012-0910-7

$\mathrm{N}$-methylurea) were also the most represented in the experimental channels, in proportions similar to those noted in the field. Comparable proportions and composition were expected since both "quantitative" and "accumulative" POCIS operate with the same sampling rates and were exposed simultaneously, in similar conditions. Indeed, high correlations were observed between the spiking solution (extracted from "accumulative" POCIS) and in situ concentrations in the contaminated site ("quantitative" POCIS), in terms of relative proportions (Pearson correlation: $0.798, p=$ 0.002) and ranks (Spearman correlation: 0.924, $p<0.0001$ ) of substances.

Changes in periphytic communities with time and exposure

Communities from $\mathrm{C}$ channels had initial global biomass (DW, AFDM) and proportion of brown algae comparable to those from R (Table 3). However, algal biomass as measured through Chl $a$ content was much lower in $\mathrm{C}$, as well as $\Phi_{\text {PSII }}(\mathrm{p}<0.001$ for both parameters). In both $\mathrm{R}$ and $\mathrm{R} / \mathrm{C}$ channels, biomass growth as measured by $\mathrm{DW}$ and AFDM reached equilibrium within 2-5 days after an increase during the first days of the experiment. The growth phase of the algal component (Chl a, diatom density) lasted longer, and stabilized between 9 and 13 days (data not shown).

At the end of the experiment, significantly higher DW and AFDM were recorded in C with comparison to $\mathrm{R}$ and $\mathrm{R} / \mathrm{C}$ (treatment*date effect, $p=0.0011$ and $p=0.0013$ respectively). In contrast, lower $\operatorname{Chl} a$, diatom cell density (both $p<0.001)$ and $\Phi_{\text {PSII }}(p=$ 0.0205) were measured in C. No significant difference was observed between R and R/C.

In all samples, pigment composition showed that diatoms dominated within the algae. Initial richness was similar in $\mathrm{R}$ and $\mathrm{C}(35 \pm 3$ vs. $32 \pm 2$ taxa). $\mathrm{R}$ and $\mathrm{R} / \mathrm{C}$ community 
Author-produced version of the article published in Ecotoxicology,2012, vol. 21 (5), 1570-1580.

The original publication is available at http://www.springerlink.com

doi : $10.1007 / \mathrm{s} 10646-012-0910-7$

structure changed more over the duration of the experiment than in C (Figure 2). $R$ communities were composed of 47 species and dominated by an association of Achnanthidium minutissimum $(27.6 \pm 1.5 \%$ relative abundance), Nitzschia capitellata $(23.9 \pm 2.1 \%)$ and Gomphonema exilissimum $(13.6 \pm 0.7 \%)$, whereas among the 43 species identified in C samples, Hantzschia amphyoxis (which was absent in R) reached $66.9 \pm 3.7 \%$ relative abundance. At the end of the 14 days of the experiment, $C$ communities were still dominated by Hantzschia amphyoxis; while higher relative abundances of Achnanthidium minutissimum (56.8 $1.3 \%)$, Fragilaria capucina $(11.0 \pm 1.1 \%)$ and Nitzschia palea $(12.8 \pm 1.7 \%)$ were recorded in R and R/C.

Based on photosynthetic efficiency, mixture $\mathrm{EC}_{50}\left(\mathrm{EC}_{50} \mathrm{mix}\right)$ values of $\mathrm{R}$ and $\mathrm{R} / \mathrm{C}$ biofilms were 4-fold lower than those from $\mathrm{C}$ natural biofilms ( $\mathrm{C}$ before exposure). $\mathrm{C}$ tolerance was significantly higher than that of $\mathrm{R}$ and $\mathrm{R} / \mathrm{C}(p<0.001)$, but decreased dramatically toward the end of the experiment $(p<0.001)$ from about $694 \pm 124 \mu \mathrm{g}\left[\right.$ total pesticides] $\cdot \mathrm{I}^{-}$ ${ }^{1}$ (i.e. more than 480 times the concentration recorded in the field) to $347 \pm 39 \mu \mathrm{g}$ [total pesticides] $\cdot \mathrm{l}^{-1}$. Globally, $\mathrm{EC}_{50} \mathrm{mix}$ values were exponentially correlated with average exposure to POCIS extracts (raw data, $\mathrm{n}=15: \mathrm{EC}_{50} \mathrm{mix}=143.5 \mathrm{e}^{1.1^{*} \text { [total pesticides], }} \mathrm{R}^{2}=0.88$, $p<0.0001)$. However, no significant difference in $\mathrm{EC}_{50}$ mix values with time or changes in exposure was observed for R and R/C.

Relationships between biofilm endpoints and environmental conditions

Partial constrained ordination (variance partitioning) decomposed the variance explained by environmental data into $31.8 \%$ of total variance ascribed to physical determinants and $34.0 \%$ to chemical parameters. $21.0 \%$ was shared by both physical 
Author-produced version of the article published in Ecotoxicology,2012, vol. 21 (5), 1570-1580.

The original publication is available at http://www.springerlink.com

doi : $10.1007 / \mathrm{s} 10646-012-0910-7$

and chemical parameters, underlying the fact that complex environmental interactions drive biofilm structure and function. Partial RDA analyses run with physical data ordered biofilm descriptors based on temperature, $\mathrm{pH}$ and conductivity that were positively correlated with biomass (AFDM, DW, diatom densities and total Chl $a$ content; Figure 3A). Chemical data (Figure 3B) indicated that higher biomass was correlated with increasing nutrient concentrations, whereas tolerance to POCIS extracts $\left(\mathrm{EC}_{50}\right)$ and diatom mortality were clearly related to concentrations of pesticide mixtures, and, to a lesser extent, to copper and arsenic concentrations.

\section{Discussion}

Use of POCIS extracts to improve exposure realism in laboratory experiments

The analytical advantages of passive sampling have been documented elsewhere (Mazzella et al. 2010; Zabiegała et al. 2010). POCIS extracts were used for both ensuring in the channels a realistic exposure to complex mixtures and performing ecotoxicological tests using the pesticide mixture as a "black box". Exposure in the channels was representative of the substances most abundant in the field and consistent with land use in the watershed (Rabiet et al. 2010). POCIS devices provided a large range of molecules for realistic exposure (Lissalde et al. 2011), both in terms of ranking, relative proportions of pesticides, and concentrations - even though they were slightly lower than those measured in situ. The use of POCIS extracts in laboratory experiments thus improves current approaches aiming to experimentally assess the impact of pesticide combinations (Chèvre et al. 2006; Knauert 2008; Knauert et al. 2008). The PICT tests were performed using dilutions of POCIS extracts as a mixture of 
Author-produced version of the article published in Ecotoxicology,2012, vol. 21 (5), 1570-1580.

The original publication is available at http://www.springerlink.com

doi : 10.1007/s10646-012-0910-7

contaminants. The combined effects of substances are hard to characterize in complex mixtures as found in the field and testing compounds individually, together with their binary, ternary, etc. mixtures, is almost impossible. Such an approach offers a good opportunity to evaluate mixture effects without the need to make an a priori selection of the pesticides tested.

Some difficulties inherent to chronic exposure experiments in semi-static laboratory systems appeared here, with the decrease of mixture concentrations between water renewals, averaging 56\% during the first week in both channels, and 30\% during the following week (data not shown). Toxicant losses mostly by adsorption onto abiotic and biotic surfaces are commonly observed in chronic exposure experiments (e.g. Riedl and Altenburger 2007). Degradation of substances was also observed in R/C channels: a slight production of the breakdown product $\mathrm{N}$-(3,4-dichlorophenyl)-N-methylurea $(+30 \%)$ happened during the second week of the experiment, concomitantly with the decrease $(-27 \%)$ of its parent substance diuron. Losses in contaminants can be compensated for by more frequent or flow-through inputs. However, numerous pollution additions (a fortiori continuous) would require large quantities of toxicants that may be difficult to obtain for financial or logistical reasons (e.g. here extracts of 16 POCIS were needed for only two low-dose contamination operations), and would generate a high quantity of pollutant to be subsequently processed (treatment of toxic waste). Another alternative would be the miniaturization of the experimental systems.

Community ecotoxicology: complementary use of structural and functional endpoints to assess mixture toxicity 
Author-produced version of the article published in Ecotoxicology,2012, vol. 21 (5), 1570-1580.

The original publication is available at http://www.springerlink.com

doi : $10.1007 / \mathrm{s} 10646-012-0910-7$

Assessing the effects of chemicals is generally based on biomarker approaches: the consequences of pollution are investigated at the level of the population, individual or sub-individual but interpretation of experimental results cannot be extrapolated to the larger scales of community or ecosystem (Forbes et al. 2006). Many authors have underlined the need to reinforce the ecological relevance of ecotoxicological studies (e.g. Relyea and Hoverman 2006; Schmitt-Jansen et al. 2008) such as approaches combining structural and functional endpoints at the community level (Geiszinger et al. 2009).

Here differences in global characteristics of the periphytic community were mainly driven by parameters other than toxicant exposure (Figure 3). Time and environmental parameters (here temperature, $\mathrm{pH}$ and light) played a major role in discrimination between samples. Environmental conditions are known to mitigate toxicity (e.g. Guasch et al. 2004; Tlili et al. 2010), and the multivariate analysis of the data allowed us to partly discriminate between the effects of generally concomitant land-use factors like nutrients, pesticides and metals. From identical diatom community structure, low dose exposure did not lead to divergence between communities, with changes in species composition mostly due to experiment duration. The concentrations of toxicants were thus probably too low to drive changes in diatoms (Morin et al. 2008; Ricart et al. 2009). Most ecotoxicological tests are based upon the assumption that a threshold concentration of toxicant has to be exceeded to provoke visible/measurable effects. In this experiment no increase in tolerance (based on $\mathrm{EC}_{50}$ values) was noted in $\mathrm{R} / \mathrm{C}$ communities with comparison to initial tolerance levels $(p=0.50)$ : at the time scale studied, neither physiological adaptation nor species selection was sufficient to increase tolerance to low doses of POCIS extracts. In $\mathrm{C}$ biofilms, $\mathrm{EC}_{50}$ mix significantly decreased following chronic exposure to the POCIS extracts. The exponential relationship between previous exposure and $\mathrm{EC}_{50} \mathrm{~s}$ had also been demonstrated for diuron by Pesce et al. 
Author-produced version of the article published in Ecotoxicology,2012, vol. 21 (5), 1570-1580.

The original publication is available at http://www.springerlink.com

doi : 10.1007/s10646-012-0910-7

(2010). This tolerance loss of formerly adapted communities following a 2-wk low dose exposure suggests either physiological adaptation of the community and/or decreased tolerance linked to increasing amounts of sensitive organisms. Final diatom community composition of $\mathrm{R}$ and $\mathrm{R} / \mathrm{C}$ was fairly similar (Figure 2), suggesting physiological adaptation rather than species selection. Laviale et al. (2011) also observed in biofilms exposed to isoproturon and atrazine a rapid recovery of the fluorescence parameters $\left(\Phi_{\mathrm{PSII}}\right.$ and $\left.\mathrm{F}_{\mathrm{v}} / \mathrm{F}_{\mathrm{m}}\right)$, proving that the response to environmental concentrations was mainly linked to down-regulation of photosystem II, rather than to photosynthetic damage.

Combining the use of structural and functional descriptors provides a more integrated overview of the processes occurring, with structural information (biomass, community composition) related here to "temporal" variations (that may either indicate successions but also the impact of laboratory conditions). Heterotrophic function was not affected, whereas photosynthesis differed depending on the origin of the biofilm and the level of contamination imposed. All together these results infer that a certain level of pressure has to be reached to induce community tolerance $(\mathrm{R} / \mathrm{C})$, and that tolerance would probably not last over long periods in the event of decreasing exposure (C), in accordance with the observations of Aldén Demoling and Bååth (2008) in polluted soils.

\section{Conclusions}

Ecotoxicology can notably benefit from the development of chemical tools. This study is the first to report the use of POCIS extracts to investigate the effects of realistic low-dose pesticide mixtures on natural biofilm communities in experimental systems. These data show almost no change in community structure and some decrease in tolerance to the 
Author-produced version of the article published in Ecotoxicology,2012, vol. 21 (5), 1570-1580.

The original publication is available at http://www.springerlink.com

doi : $10.1007 / \mathrm{s} 10646-012-0910-7$

major contaminants composing the cocktail with decreasing levels of contamination,

However, the results do provide a basis for further ecotoxicology studies and point out the pros and cons of this kind of experimental design, especially increasing environmental realism by combining realistic exposure and the effects on complex communities but also the necessity to improve the exposure conditions, in particular, keeping the concentrations stable.

Acknowledgements

The French National Office for the Aquatic Environment (ONEMA-CEMAGREF agreement, action 26) and the Cemagref's "PestExpo" Research Program provided financial support for this experiment. The authors thank Marjorie Maréchal, Bernard Motte, Cécile Nassiet, Christophe Rosy, Bernadette Volat and Josiane Gahou for technical help.

References

Aldén Demoling L, Bååth E (2008) No long-term persistence of bacterial PollutionInduced Community Tolerance in tylosin-polluted soil. Environ Sci Technol 42 (18):6917-6921. doi:10.1021/es8004706

Alvarez DA, Petty JD, Huckins JN, Jones-Lepp TL, Getting DT, Goddard JP, Manahan SE (2004) Development of a passive, in situ, integrative sampler for hydrophilic organic contaminants in aquatic environments. Environ Toxicol Chem 23 (7):1640-1648

Artigas J, Arts G, Babut M, Caracciolo AB, Charles S, Chaumot A, Combourieu B, Dahllöf I, Despréaux D, Ferrari B, Friberg N, Garric J, Geffard O, Gourlay-Francé C, Hein M, Hjorth M, Krauss M, De Lange HJ, Lahr J, Lehtonen KK, Lettieri T, Liess M, Lofts S, Mayer P, Morin S, Paschke A, Svendsen C, Usseglio-Polatera P, van den Brink N, Vindimian E, Williams R (2012) Towards a renewed research agenda in ecotoxicology. Environ Pollut 160:201-206 
Baker NR (2008) Chlorophyll fluorescence: A probe of photosynthesis in vivo. Annual $\begin{array}{lllll}\text { Review of } & \text { Plant } & & \end{array}$ doi:doi:10.1146/annurev.arplant.59.032607.092759

Blanck H, Wängberg SA, Molander S (1988) Pollution-Induced Community Tolerance - A new ecotoxicological tool. In: Functional Testing of Aquatic Biota for estimating Hazards of Chemicals. Cairns J. Jr, Pratt J.R. (Eds), Philadelphia, pp 219-230

Chèvre N, Loepfe C, Singer H, Stamm C, Fenner K, Escher BI (2006) Including mixtures in the determination of water quality criteria for herbicides in surface water. Environ Sci Technol 40 (2):426-435. doi:10.1021/es050239l

Choubert J-M, Martin-Ruel S, Coquery M (2009) Prélèvement et échantillonnage des substances prioritaires et émergentes dans les eaux usées. Les prescriptions techniques du projet de recherche AMPERES. Techniques Sciences Méthodes 4:88-101

Dorigo U, Leboulanger C, Bérard A, Bouchez A, Humbert JF, Montuelle B (2007) Lotic biofilm community structure and pesticide tolerance along a contamination gradient in a vineyard area. Aquat Microb Ecol 50:91-102

Duong TT, Morin S, Herlory O, Feurtet-Mazel A, Coste M, Boudou A (2008) Seasonal effects of cadmium accumulation in periphytic diatom communities of freshwater biofilms. Aquat Toxicol 90 (1):19-28

Escher BI, Quayle P, Muller R, Schreiber U, Mueller JF (2006) Passive sampling of herbicides combined with effect analysis in algae using a novel high-throughput phytotoxicity assay (Maxi-Imaging-PAM). J Environ Monit 8 (4):456-464

European Commission (2009). Directive 2009/128/EC establishing a framework for Community action to achieve the sustainable use of pesticides. Directive of the European Parliament and of the Council of 21 October 2009

Forbes VE, Palmqvist A, Bach L (2006) The use and misuse of biomarkers in ecotoxicology. Environ Toxicol Chem 25 (1):272-280. doi:10.1897/05-257r.1

Geiszinger A, Bonnineau C, Faggiano L, Guasch H, López-Doval JC, Proia L, Ricart M, Ricciardi F, Romaní A, Rotter S, Muñoz I, Schmitt-Jansen M, Sabater S (2009) The relevance of the community approach linking chemical and biological analyses in pollution assessment. TrAC Trends in Analytical Chemistry 28 (5):619-626

Guasch H, Navarro E, Serra A, Sabater S (2004) Phosphate limitation influences the sensitivity to copper in periphytic algae. Freshwat Biol 49 (4):463-473

Helsel DR (1990) Less than obvious - statistical treatment of data below the detection limit. Environ Sci Technol 24 (12):1766-1774. doi:10.1021/es00082a001

Ihaka R, Gentleman R (1996) R: A language for data analysis and graphics. J Comput Graph Statist 5:299-314

Knauert S (2008) Toxicity of pesticides and their mixture to primary producers. PhD thesis - Philosophish-Naturwissenschaftlichen Fakultät, Universität Basel,

Knauert S, Escher B, Singer H, Hollender J, Knauer K (2008) Mixture toxicity of three Photosystem II inhibitors (atrazine, isoproturon, and diuron) toward photosynthesis of freshwater phytoplankton studied in outdoor mesocosms. Environ Sci Technol 42 (17):6424-6430. doi:10.1021/es072037q

Krammer K, Lange-Bertalot H (1986 - 1991) Bacillariophyceae 1. Teil: Naviculaceae. 876 p.; 2. Teil: Bacillariaceae, Epithemiaceae, Surirellaceae, 596 p.; 3. Teil: Centrales, Fragilariaceae, Eunotiaceae, 576 p.; 4. Teil: Achnanthaceae. Kritische Ergänzungen zu Navicula (Lineolatae) und Gomphonema. 437 p., vol Band 2/1-4. Süßwasserflora von Mitteleuropa. G. Fischer Verlag., Stuttgart 
Author-produced version of the article published in Ecotoxicology,2012, vol. 21 (5), 1570-1580.

The original publication is available at http://www.springerlink.com

doi : 10.1007/s10646-012-0910-7

Laviale M, Morin S, Créach A (2011) Short term recovery of periphyton photosynthesis after pulse exposition to the photosystem II inhibitors atrazine and isoproturon. Chemosphere 84 (5):731-734

Lissalde S, Mazzella N, Fauvelle V, Delmas F, Mazellier P, Legube B (2011) Liquid chromatography coupled with tandem mass spectrometry method for thirtythree pesticides in natural water and comparison of performance between classical solid phase extraction and passive sampling approaches. J Chromatogr A 1218 (11):1492-1502

Mazzella N, Dubernet J-F, Delmas F (2007) Determination of kinetic and equilibrium regimes in the operation of polar organic chemical integrative samplers: Application to the passive sampling of the polar herbicides in aquatic environments. J Chromatogr A 1154 (1-2):42-51

Mazzella N, Lissalde S, Moreira S, Delmas F, Mazellier P, Huckins JN (2010) Evaluation of the use of Performance Reference Compounds in an Oasis-HLB adsorbent based passive sampler for improving water concentration estimates of polar herbicides in freshwater. Environ Sci Technol 44 (5):1713-1719. doi:10.1021/es902256m

McCune B, Mefford MJ (1999) Multivariate analysis of ecological data, version 4.01. MJM Software, Gleneden Beach, Oregon USA,

Montuelle B, Dorigo U, Bérard A, Volat B, Bouchez A, Tlili A, Gouy V, Pesce S (2010) The periphyton as a multimetric bioindicator for assessing the impact of land use on rivers: an overview of the Ardières-Morcille experimental watershed (France). Hydrobiologia:1-19. doi:10.1007/s10750-010-0105-2

Morin S, Duong TT, Herlory O, Feurtet-Mazel A, Coste M (2008) Cadmium toxicity and bioaccumulation in freshwater biofilms. Arch Environ Contam Toxicol 54 (2):173-186

Morin S, Pesce S, Tlili A, Coste M, Montuelle B (2010a) Recovery potential of periphytic communities in a river impacted by a vineyard watershed. Ecol Indicators 10 (2):419-426

Morin S, Proia L, Ricart M, Bonnineau C, Geiszinger A, Ricciardi F, Guasch H, Romaní A, Sabater S (2010b) Effects of a bactericide on the structure and survival of benthic diatom communities. Vie Milieu 60 (2)

Oksanen J, Blanchet FG, Kindt R, Legendre P, O'Hara RB, Simpson GL, Solymos P, Stevens MHH, Wagner H (2010) vegan: Community Ecology Package. R package version 1.17-2, http://CRAN.R-project.org/package=vegan.

Pesce S, Margoum C, Montuelle B (2010) In situ relationships between spatio-temporal variations in diuron concentrations and phototrophic biofilm tolerance in a contaminated river. Water Res 44 (6):1941-1949

Pesce S, Morin S, Lissalde S, Montuelle B, Mazzella N (2011) Combining polar organic chemical integrative samplers (POCIS) with toxicity testing to evaluate pesticide mixture effects on natural phototrophic biofilms. Environ Pollut 159 (3):735-741

Pinheiro J, Bates D, DebRoy S, Sarkar D, R Core team (2009) nlme: Linear and Nonlinear Mixed Effects Models. R package version 3.1-96.

Plan Ecophyto 2018 de Réduction des Usages de Pesticides 2008-2018. Available from http://agriculture.gouv.fr/IMG/pdf/PLAN_ECOPHYTO_2018-2-2.pdf (accessed March, 2012).

Rabiet M, Margoum C, Gouy V, Carluer N, Coquery M (2010) Assessing pesticide concentrations and fluxes in the stream of a small vineyard catchment - Effect of sampling frequency. Environ Pollut 158 (3):737-748 
Author-produced version of the article published in Ecotoxicology,2012, vol. 21 (5), 1570-1580.

The original publication is available at http://www.springerlink.com

doi : $10.1007 / \mathrm{s} 10646-012-0910-7$

Relyea R, Hoverman J (2006) Assessing the ecology in ecotoxicology: a review and synthesis in freshwater systems. Ecol Lett 9 (10):1157-1171. doi:10.1111/j.1461-0248.2006.00966.x

Ricart M, Barceló D, Geiszinger A, Guasch H, Alda MLd, Romaní AM, Vidal G, Villagrasa M, Sabater S (2009) Effects of low concentrations of the phenylurea herbicide diuron on biofilm algae and bacteria. Chemosphere 76 (10):1392-1401

Riedl J, Altenburger R (2007) Physicochemical substance properties as indicators for unreliable exposure in microplate-based bioassays. Chemosphere 67 (11):22102220

Schmitt-Jansen M, Altenburger R (2008) Community-level microalgal toxicity assessment by multiwavelength-excitation PAM fluorometry. Aquat Toxicol 86 (1):49-58

Schmitt-Jansen M, Veit U, Dudel G, Altenburger R (2008) An ecological perspective in aquatic ecotoxicology: Approaches and challenges. Basic Appl Ecol 9 (4):337-345

Shaw M, Negri A, Fabricius K, Mueller JF (2009) Predicting water toxicity: Pairing passive sampling with bioassays on the Great Barrier Reef. Aquat Toxicol 95 (2):108-116

Tlili A, Bérard A, Roulier J-L, Volat B, Montuelle B (2010) $\mathrm{PO}_{4}{ }^{3-}$ dependence of the tolerance of autotrophic and heterotrophic biofilm communities to copper and diuron. Aquat Toxicol 98 (2):165-177

Tlili A, Marechal M, Montuelle B, Volat B, Dorigo U, Bérard A (2011) Use of the MicroResp(TM) method to assess pollution-induced community tolerance to metals for lotic biofilms. Environ Pollut 159 (1):18-24

Tlili A, Montuelle B (2011) Microbial Pollution-Induced Community Tolerance. In: Amiard-Triquet C, Rainbow PS, Roméo M (eds) Tolerance to Environmental Contaminants. CRC Press, pp 85-108

Ylla I, Borrego C, Romaní AM, Sabater S (2009) Availability of glucose and light modulates the structure and function of a microbial biofilm. FEMS Microbiol Ecol 69 (1):27-42. doi:10.1111/j.1574-6941.2009.00689.x

Zabiegała B, Kot-Wasik A, Urbanowicz M, Namieśnik J (2010) Passive sampling as a tool for obtaining reliable analytical information in environmental quality monitoring. Anal Bioanal Chem 396 (1):273-296. doi:10.1007/s00216-009-3244-4 
Author-produced version of the article published in Ecotoxicology,2012, vol. 21 (5), 1570-1580.

The original publication is available at http://www.springerlink.com

doi : 10.1007/s10646-012-0910-7

Tables

Table 1: In situ water characteristics (data are average \pm standard error, $n=4$ except for Cu and As: $n=2$, and total pesticides: time-weighted average concentrations)

\begin{tabular}{lcc}
\hline parameter & reference site & contaminated site \\
\hline Temperature $\left({ }^{\circ} \mathrm{C}\right)$ & $12.5 \pm 0.3$ & $14.4 \pm 0.4$ \\
$\mathrm{pH}$ & $7.2 \pm 0.2$ & $7.5 \pm 0.2$ \\
Conductivity $\left(\mu \mathrm{S} \cdot \mathrm{cm}^{-1}\right)$ & $161.0 \pm 3.6$ & $230.7 \pm 6.0$ \\
$\mathrm{DOC}\left(\mathrm{mg}^{\mathrm{l}-1}\right)$ & $2.9 \pm 0.3$ & $4.7 \pm 0.7$ \\
$\mathrm{NO}_{3}\left(\mathrm{mg}^{\mathrm{I} \cdot 1}\right)$ & $5.6 \pm 0.4$ & $6.9 \pm 1.5$ \\
$\mathrm{PO}_{4}\left(\mathrm{mg}{ }^{\mathrm{l}-1}\right)$ & $0.1 \pm 0.0$ & $0.2 \pm 0.0$ \\
$\mathrm{Copper}\left(\mu \mathrm{g} \cdot \mathrm{I}^{-1}\right)$ & 1.3 & 10.0 \\
Arsenic $\left(\mu \mathrm{g} \cdot{ }^{\mathrm{l}-1}\right)$ & 1.9 & 8.5 \\
\hline Total pesticides $\left(\mu \mathrm{g} \cdot \mathrm{I}^{-1}\right)$ & 0.1 & 1.7 \\
\hline
\end{tabular}


Table 2: Pesticide concentrations measured in situ, in the experimental channels and in the spiking solution (concentration of the "accumulative" POCIS extract) used for PICT tests. nm: not measured.

\begin{tabular}{|c|c|c|c|c|c|c|}
\hline \multirow{2}{*}{ Concentration $\left(\mu g \cdot l^{-1}\right)$} & \multirow{2}{*}{ Family } & \multicolumn{2}{|c|}{ In situ conditions ${ }^{1}$} & \multicolumn{2}{|c|}{ Experimental conditions $^{2}$} & \multirow{2}{*}{ Spiking solution } \\
\hline & & reference site & contaminated site & $\mathrm{R} / \mathrm{C}$ & C & \\
\hline Azoxystrobin & Strobilurin & $<0.01$ & 0.09 & $<0.02$ & $<0.02$ & 62 \\
\hline Cyproconazole & Triazole & $\mathrm{nm}$ & $\mathrm{nm}$ & 0.02 & $<0.02$ & $<0.02$ \\
\hline Deethylterbuthylazine & Triazine & 0.01 & 0.02 & $<0.02$ & $<0.02$ & 13 \\
\hline Deisopropylatrazine & Triazine & 0.02 & 0.02 & $<0.02$ & $<0.02$ & 10 \\
\hline Diflufenican & Carboxymide & $<0.02^{*}$ & $<0.02^{*}$ & 0.01 & $<0.01$ & $<0.02$ \\
\hline Dimetomorph & Morpholine & 0.01 & 0.86 & $0.20 \pm 0.03$ & $0.27 \pm 0.08$ & 394 \\
\hline Diuron & Phenylurea & 0.03 & 0.23 & $0.08 \pm 0.01$ & $0.11 \pm 0.04$ & 174 \\
\hline $\mathrm{N}-(3,4$-dichlorophenyl)-N-methylurea & $\begin{array}{l}\text { Phenylurea / } \\
\text { Breakdown product }\end{array}$ & $<0.02$ & 0.11 & $0.04 \pm 0.01$ & $0.06 \pm 0.01$ & 58 \\
\hline $\mathrm{N}$-(3,4-dichlorophenyl)-urea & $\begin{array}{l}\text { Phenylurea / } \\
\text { Breakdown product }\end{array}$ & $<0.03$ & $<0.03$ & $<0.03$ & $<0.03$ & 16 \\
\hline Norflurazon & Pyridazinone & $0.02^{*}$ & $0.15^{*}$ & 0.04 & 0.11 & 112 \\
\hline Procymidone & Dicarboxymide & $<0.02^{*}$ & $0.03^{*}$ & $<0.02$ & $<0.02$ & 28 \\
\hline Simazine & Triazine & $<0.01$ & 0.08 & $0.02 \pm 0.00$ & $0.03 \pm 0.00$ & 24 \\
\hline Tebuconazole & Triazole & $<0.02^{*}$ & $0.10^{*}$ & 0.06 & 0.32 & 320 \\
\hline Terbuthylazine & Triazine & $<0.01$ & 0.03 & $<0.02$ & $<0.02$ & 23 \\
\hline Total & & 0.09 & 1.71 & $0.42 \pm 0.06$ & $0.66 \pm 0.33$ & 1920 \\
\hline
\end{tabular}

${ }_{1}^{1}$ Time-weighted average concentrations using POCIS exposed for 2-weeks, except for *: spot measurements performed mid-period

${ }^{2}$ Spot samplings: values are average \pm standard error $(n=6)$ or mean values for fungicides $(n=2)$. 
Author-produced version of the article published in Ecotoxicology,2012, vol. 21 (5), 1570-1580

The original publication is available at http://www.springerlink.com

doi : 10.1007/s10646-012-0910-7

Table 3: Biofilm characteristics at the beginning (day 0 ) and the end (day 14) of the experiment in the $R, C$ and $R / C$ channels. Biomass data are expressed per $\mathrm{cm}^{2}$ colonized substrate. The superscript letters indicate statistical differences according to LmE results $(p<0.05)$. nm: not measured.

\begin{tabular}{|c|c|c|c|c|c|}
\hline \multirow[b]{2}{*}{ Average ( \pm standard error) } & \multicolumn{2}{|c|}{$\mathbf{R}$} & \multicolumn{2}{|c|}{$\mathbf{C}$} & \multirow{2}{*}{$\begin{array}{c}\text { R/C } \\
\text { day } 14\end{array}$} \\
\hline & day 0 & day 14 & day 0 & day 14 & \\
\hline \multicolumn{6}{|l|}{ Structural characteristics } \\
\hline Dry weight $\left(\mathrm{mg}^{\prime} \mathrm{cm}^{-2}\right)$ & $0.31 \pm 0.02^{a}$ & $0.66 \pm 0.05^{b}$ & $0.44 \pm 0.02^{a}$ & $0.93 \pm 0.43^{c}$ & $0.67 \pm 0.10^{b}$ \\
\hline Ash-free dry mass $\left(\mathrm{mg} \cdot \mathrm{cm}^{-2}\right)$ & $0.13 \pm 0.00^{a}$ & $0.35 \pm 0.01^{\mathrm{b}}$ & $0.12 \pm 0.04^{a}$ & $0.40 \pm 0.19^{c}$ & $0.37 \pm 0.04^{b}$ \\
\hline Chlorophyll a $\left(\mu \mathrm{g} \cdot \mathrm{cm}^{-2}\right)$ & $4.18 \pm 0.33^{\mathrm{a}}$ & $14.05 \pm 2.13^{b}$ & $3.40 \pm 0.27^{\mathrm{c}}$ & $8.96 \pm 0.45^{d}$ & $14.06 \pm 1.69^{b}$ \\
\hline$\%$ Brown algae & $84.8 \pm 0.5$ & $90.0 \pm 0.6$ & $88.1 \pm 0.6$ & $64.5 \pm 2.2$ & $89.7 \pm 0.6$ \\
\hline Diatom density (x 1000 cells $\left.\cdot \mathrm{cm}^{-2}\right)$ & $261 \pm 33^{a}$ & $1051 \pm 117^{b}$ & $695 \pm 66^{c}$ & $540 \pm 151^{\mathrm{c}}$ & $1270 \pm 133^{b}$ \\
\hline Diatom mortality (\%) & $14.5 \pm 3.7^{\mathrm{a}}$ & $17.3 \pm 3.2^{a}$ & $24.7 \pm 0.8^{b}$ & $30.0 \pm 3.7^{b}$ & $16.0 \pm 3.6^{a}$ \\
\hline \multicolumn{6}{|l|}{ Functional characteristics } \\
\hline$\Phi_{\mathrm{PSII}}$ & $0.59 \pm 0.01^{a}$ & $0.53 \pm 0.01^{b}$ & $0.50 \pm 0.01^{b}$ & $0.38 \pm 0.02^{c}$ & $0.51 \pm 0.01^{b}$ \\
\hline$E C_{50} F_{v} / F_{m}\left(\mu g \cdot I^{-1}\right)$ & $176 \pm 10^{a}$ & $142 \pm 7^{\mathrm{a}}$ & $694 \pm 124^{b}$ & $347 \pm 39^{c}$ & $173 \pm 17^{a}$ \\
\hline Respiration $\left(\mu \mathrm{gCO}_{2} \cdot \mathrm{Cm}^{-2}\right)$ & $191 \pm 10$ & $195 \pm 5$ & $\mathrm{~nm}$ & $\mathrm{~nm}$ & $188 \pm 19$ \\
\hline
\end{tabular}




\section{Figure captions}

Figure 1: Experimental set-up. A- Triplicate channels fed by the same tank, used for R (artificial water) and R/C (artificial water + POCIS extracts) treatments. B- Independent channels fed by individual tanks, used for $\mathbf{R}$ (artificial water, 1 tank), R/C (artificial water + POCIS extracts, 1 tank) and C (artificial water + POCIS extracts, 1 tank) treatments. Channel dimensions are: $1 \times w \times d=63 \times 11 \times 4 \mathrm{~cm}$. Arrows indicate direction of flow.

Figure 2. Sample clustering based on community structure (using species accounting for more than $2 \%$ relative abundance in at least one sample) and proportion of the main species: ADMI- Achnanthidium minutissimum, EOMI- Eolimna minima, FCAP- Fragilaria capucina, GPAR-Gomphonema parvulum, GEXL- G. exilissimum, NCPL- Nitzschia capitellata, NPAL- N. palea, SANG- Surirella angusta.

Figure 3. Triplots based on redundancy analysis of data, with emphasis on A) physical parameters and B) chemical parameters, including toxicants. Circles correspond to biofilms sampled before exposure to channel conditions (day 0), diamonds to samples collected at the end of the experiment (day 14). White symbols: R, grey symbols: R/C, black symbols: C. Biofilm-related endpoints are: DW, AFDM, total chlorophyll $a$ content (Chlo_tot), \% brown algae (Brown_Algae), functional parameters $\left(\Phi_{\mathrm{PSI}}, \mathrm{EC}_{50} \mathrm{~F}_{\mathrm{v}} / \mathrm{F}_{\mathrm{m}}\right)$, diatom number of live cells (Densities) and \% of dead cells (Mortality), 
Author-produced version of the article published in Ecotoxicology,2012, vol. 21 (5), 1570-1580.

The original publication is available at http://www.springerlink.com

doi : 10.1007/s10646-012-0910-7

Fig. 1

\section{A- Triplicate channels}

$$
\overline{/ 1111} \text { artificial light }
$$

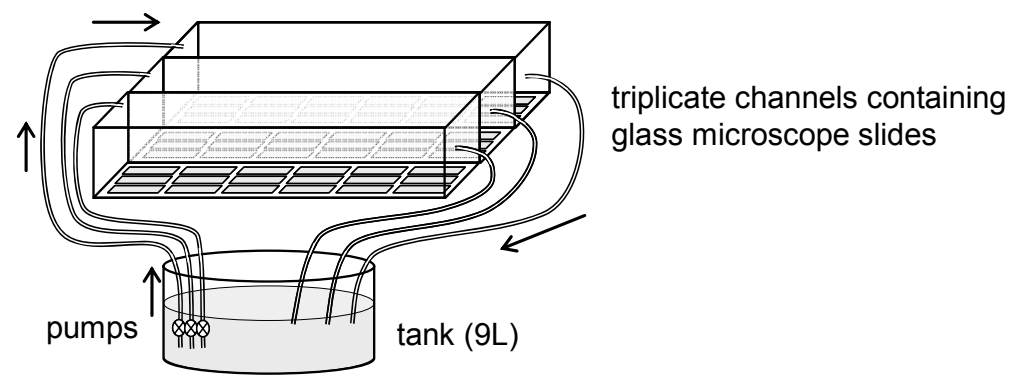

\section{B- Independent channels}

$$
\overline{/ 1111} \text { artificial light }
$$

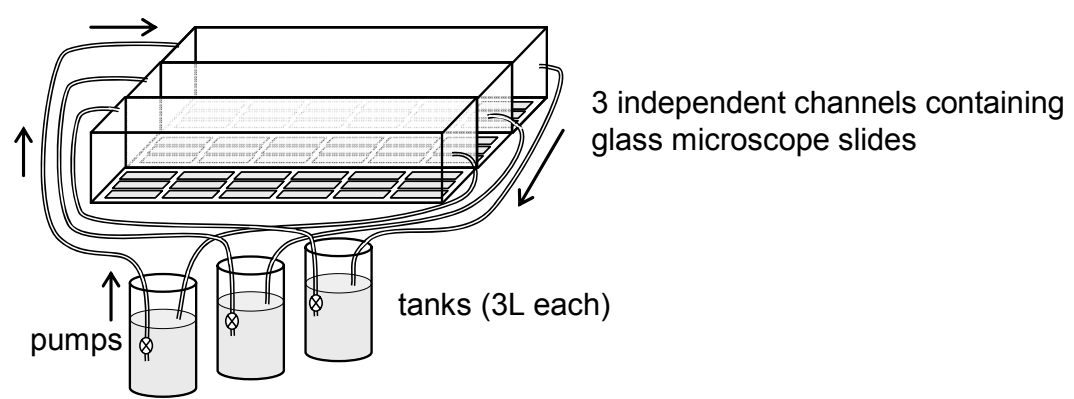


Author-produced version of the article published in Ecotoxicology,2012, vol. 21 (5), 1570-1580.

The original publication is available at http://www.springerlink.com

doi : 10.1007/s10646-012-0910-7

Fig. 2

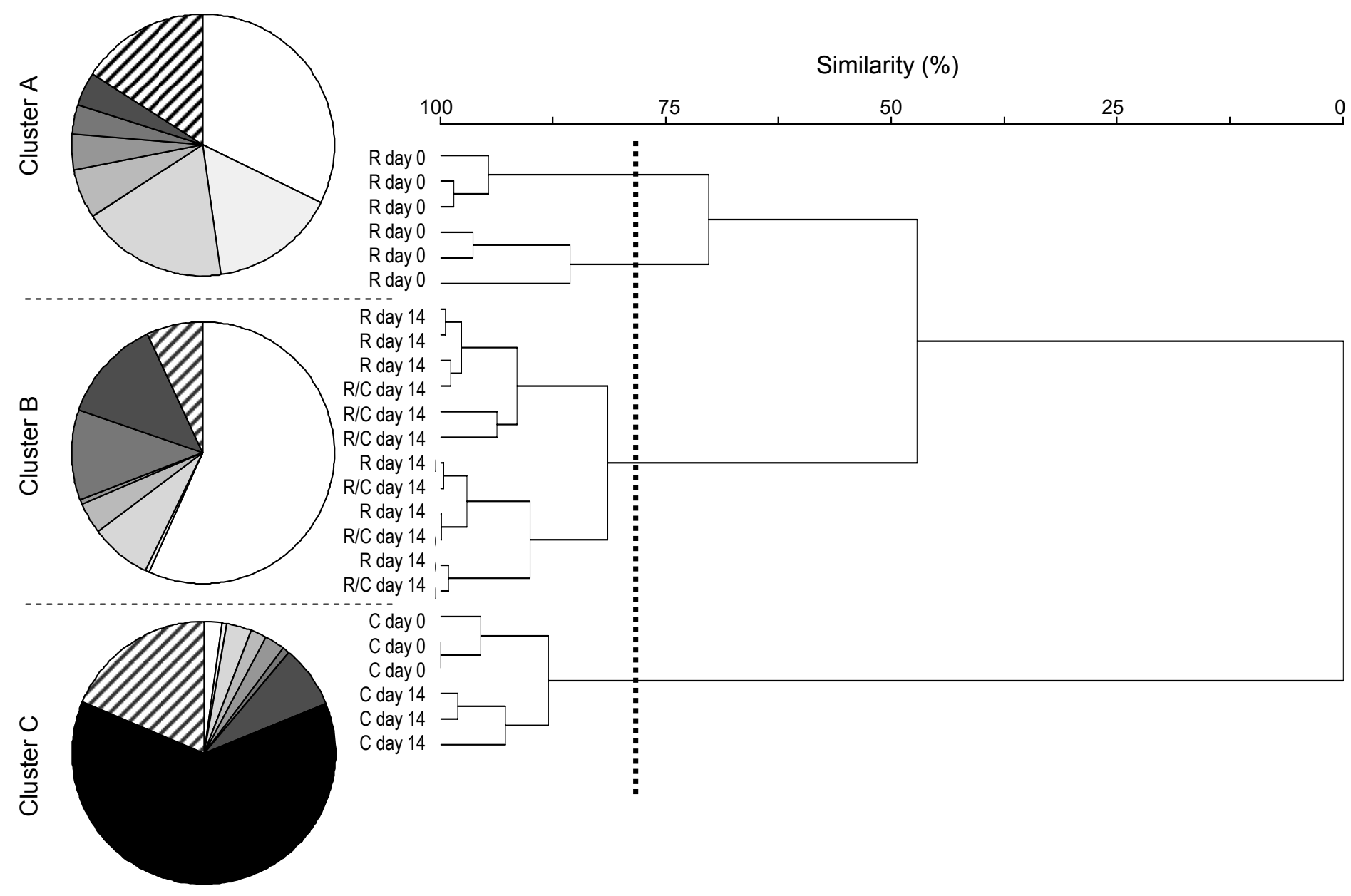

$\square$ ADMI $\square$ NCPL $\square$ GPAR+GEXL $\square$ EOMI $\square$ SANG $\square$ FCAP $\square$ NPAL $\square$ HAMP $\square$ Others 
Author-produced version of the article published in Ecotoxicology,2012, vol. 21 (5), 1570-1580 The original publication is available at http://www.springerlink.com

1007/s10646-012-0910-7

Fig. 3

A

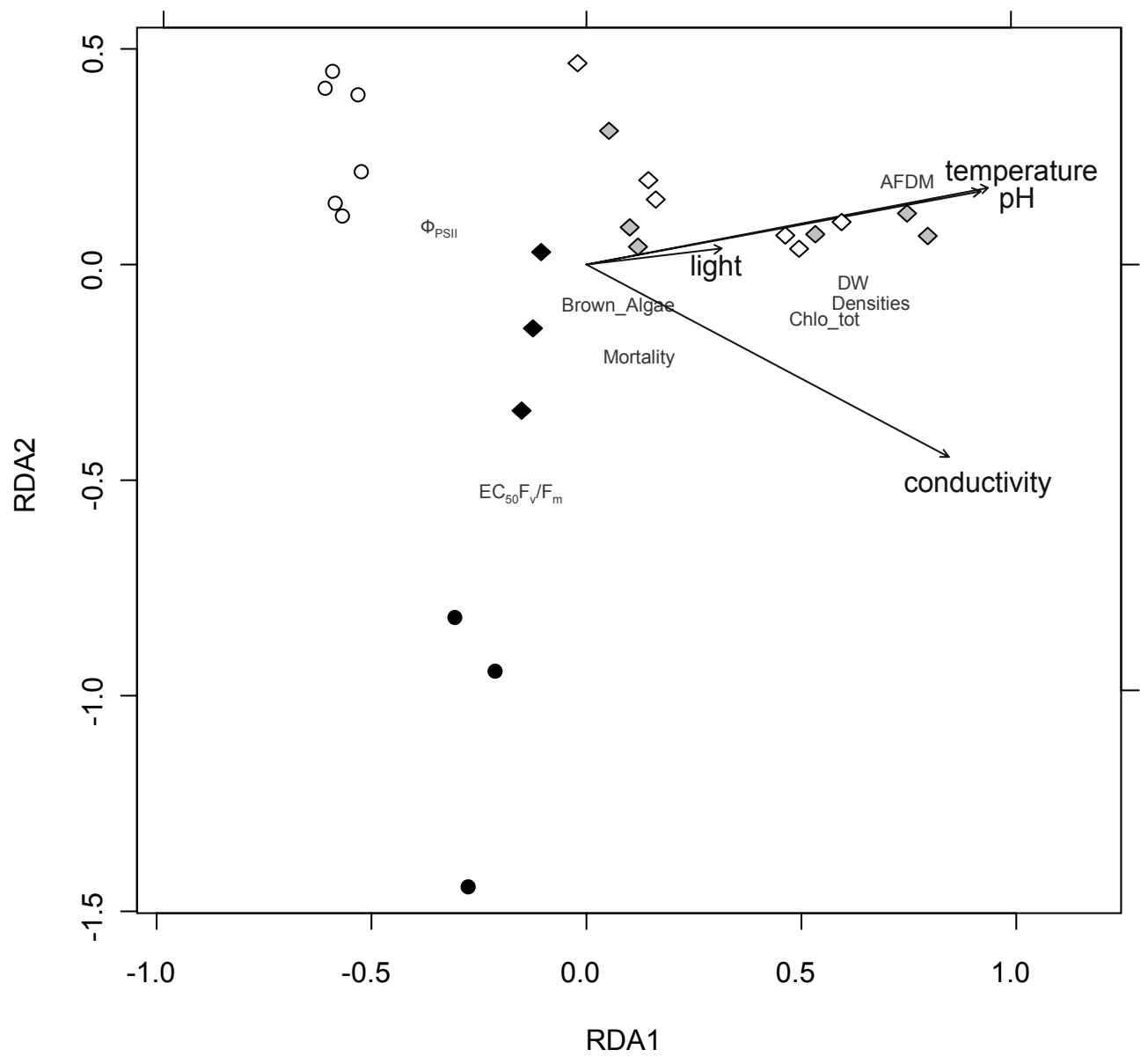

B

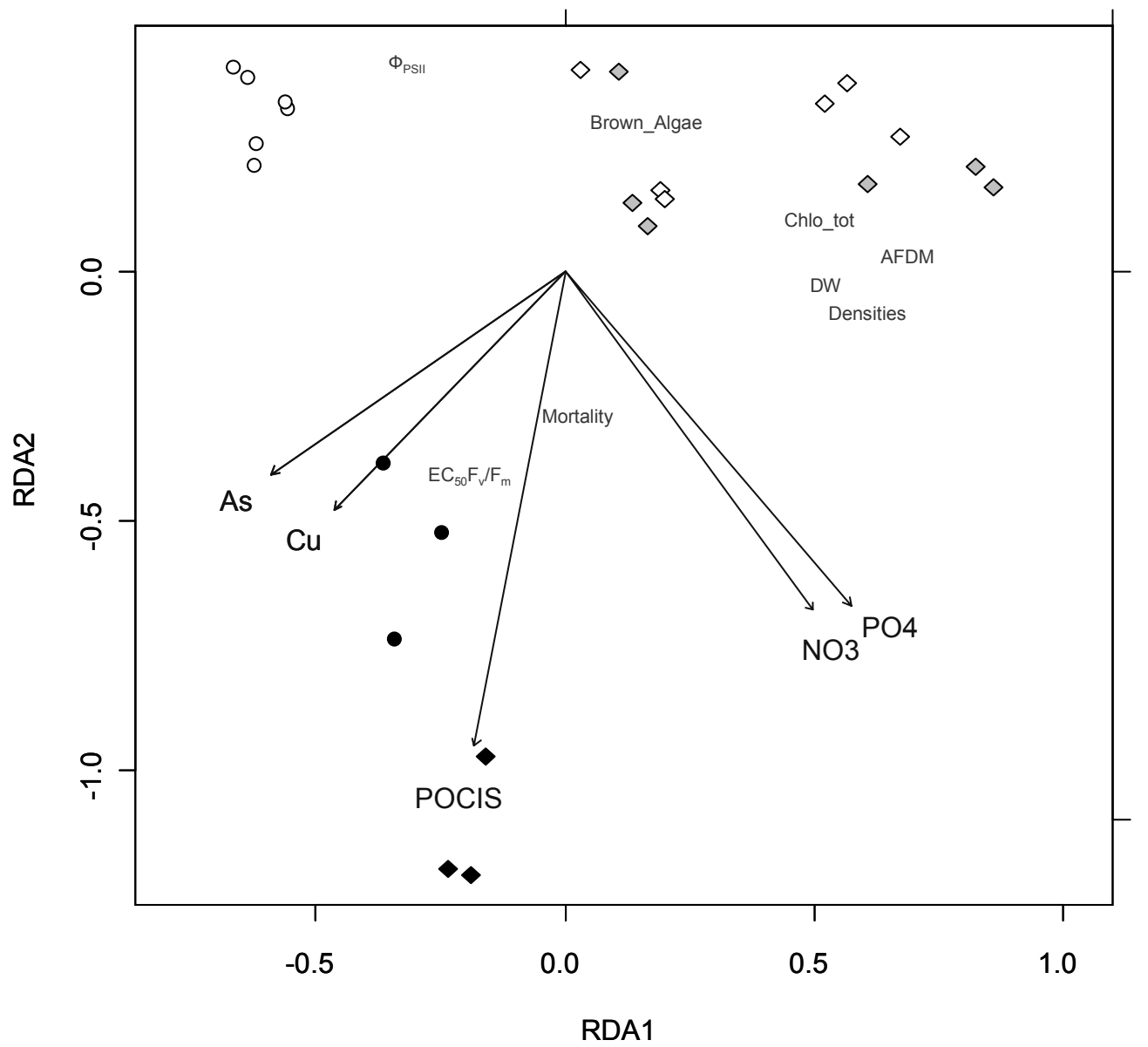

